Relations industrielles

Industrial Relations

\title{
La médecine en mutation, par Dr Jacques Mététrier, Collection Mutations-Orientations, Casterman/poche, Paris, 1970, 159 pp.
}

\section{Réjeane Guy}

Volume 26, numéro 1, 1971

URI : https://id.erudit.org/iderudit/028213ar

DOI : https://doi.org/10.7202/028213ar

Aller au sommaire du numéro

Éditeur(s)

Département des relations industrielles de l'Université Laval

ISSN

0034-379X (imprimé)

1703-8138 (numérique)

Découvrir la revue

Citer ce compte rendu

Guy, R. (1971). Compte rendu de [La médecine en mutation, par Dr Jacques Mététrier, Collection Mutations-Orientations, Casterman/poche, Paris, 1970, 159 pp.] Relations industrielles / Industrial Relations, 26(1), 257-258.

https://doi.org/10.7202/028213ar

Tous droits réservés @ C Département des relations industrielles de l'Universite Laval, 1971
Ce document est protégé par la loi sur le droit d'auteur. L'utilisation des services d'Érudit (y compris la reproduction) est assujettie à sa politique d'utilisation que vous pouvez consulter en ligne.

https://apropos.erudit.org/fr/usagers/politique-dutilisation/ 
auxquelles s'appliquent les différents mécanismes de participation analysés au chapitre II. II y aurait les décisions reliées aux politiques générales et celles reliées à des domaines déterminés de l'activité de l'entreprise : aspects économiques, emploi et politique de personnel, rémunération et conditions de travail, bien-être et plan socio-culturel.

Résultat de discussions d'experts dans ce domaine, basé sur une documentation des plus riches, ce rapport est d'un intérêt considérable pour tous ceux qui s'intéressent au problème de la participation des travailleurs aux décisions de lentreprise et à ses solutions.

\section{Jean-Pierre BEAULIEU}

\section{Structural Unemployment Theory and Measurement, by G. Peter Penz, Pro- gram Development Service, Depart- ment of Manpower and Immigration, Ottawa, 1969. Pp. ix +91 .}

Structural unemployment was a major topic of controversy during the sixties. More recently, the controversy seems to have been settled largely in favour of the aggregate demand school which holds the view that management of the economy should be based primarily, though not exclusively, on the traditional fiscal/monetary tools of stabilisation policy.

It appears, however, that structuralist sympathies have left deep roots in the Canada Department of Manpower and Immigration, which has recently sponsored the publication of a new book on the subject.

The book, based on the author's M.A. Thesis written at the University of British Columbia, is primarily a theoretical work. The longest chapter (Chapter II) is a survey of literature - a task which was adequately performed by others before, notably by J.W.L. Winder in The Canadian Labour Market edited by A. Kruger and N.M. Meltz, which book the Canada Department of Manpower and Immigration had also sponsored (in conjuction with the Centre for Industrial Relations at the University of Toronto).

Perhaps the most noteworthy aspect of this book is its attempt at utilizing job vacancy data for the measurement of Canadian structural unemployment (Chapters III and IV). Drawing upon some partial vacancy data from the old N.E.S. sources and the now defunct DBS Hirings and Separations survey, the author estimates that structural unemployment in Canada was nearly $4 \%$ in the 1960 's, up from $3 \%$ in the early 1950's (p. 87).

This might be an opportune moment to refer to the current state of Canadian job vacancy survey which is being jointly developed by the DBS and the Department of Manpower and Immigration. Once regular data are released, labour market analysis, both for theoretical and policy purposes, will be significantly stimulated. This will be particularly true if the vacancy data could be made available within a labour turnover context. To satisfy this last requirement, a new substitute will be needed for the old Hirings and Separation survey.

\section{Ozay MEHMET}

La médecine en mutation, par Dr Jacques Ménétrier, Collection MutationsOrientations, Casterman/poche, Paris, 1970, 159 pp.

L'auteur distingue la médecine orthodoxe de la médecine hétérodoxe.

La médecine orthodoxe, c'est aussi la médecine officielle, la médecine classique. L'auteur retrace les principaux jalons qui permettent de suivre l'évolution de cette voie dite «conforme». Il y eut d'abord l'évolution pasteurienne, caractérisée par la mise en évidence des agents microbiens, la certitude acquise d'une agression et le développement de l'immunologie. Ce sont les débuts de la médecine offensive. Cette ère se poursuit avec la découverte des antibiotiques et de la chimoithérapie. Toujours le pathologique est l'objet essentiel de la médecine, le fonctionnel n'occupe qu'une place de seconde importance. Cette voie se caractérise encore par la méconnaissance de l'immatériel et par le danger de confondre le malade et la maladie.

Par opposition à cette voie « conforme », il existe une deuxième voie dans 
laquelle peut évoluer la médecine : c'est la voie «difficile». Difficile parce qu'on tient compte de l'existence du corps et de l'esprit qui transcende la matière. Cette médecine s'intéresse aux malades qui n'ont ni la santé qu'il faut protéger, ni la maladie qu'il faut combattre. L'homme y est conçu comme un être où l'équilibre des fonctions matérelles favorise le développement de la fonction supérieure: la conscience.

L'auteur conclut en affirmant que c'est dans cette seconde voie que la médecine doit définitivement s'engager afin de mieux agir dans une société future plus soucieuse de la nature humaine.

Réjane GUY

\section{PUBLICATIONS RÉCENTES}

\section{Généralités}

« The Social Consequences of Technological Progress: Critical Comments on Recent Theories 》 by William Leiss, Journal of The Institute of Public Administration of Canada, Fall 1970, vol. XIII, no 3, pp. 246-263.

«A Conceptual Framework for Government Policy-Making 》 by Malcolm Rowan, Journal of the Institute of Public Administration of Canada, Fall 1970, vol. XIII, no 3, pp. 277-297.

«Hygiène mentale du travailleur» par Claude Veil, Projet, fév. 1970, no 42, pp. 169-181.

«La participation 》 Professions et entreprises, nov. 1970 , no $625,63 \mathrm{pp}$.

«La sécurité au travail » par J.P. Hogue, Commerce, janv. 1971, 73ème année, no 1, pp. 10-12.

«The Case of International Harvester» by Will Paynter, Personnel Management, Déc. 1970 , vol. 2 , no 11 , pp.24-30.

« Méthode opérationnelle de planification du développement » par A. Waterston, Economie et humanisme, maijuin 1970, no 193 , pp. 11-30.

\& The Possible Uses and Limitations of Planning 》 by L. Bodnar, Ontario Economic Review, Sept.-Oct. 1970, vol. 8, no 5 , pp. 1-4.

«Le principe de planification - Evolution et avenir » par M. Courtheoux, Humanisme et entreprise, oct. 1970, no 63, pp. 41-49.
* The Social Characteristics of the Early Nineteenth-Century Russian Bureaucracy $\gg$ by Walter M. Pintner, Slavic Review, Sept. 1970, vol. 29, no 3, pp. 429-444.

«Le sous-développement et ses problèmes formatifs: de la domination culturelle au développement culturel 》 par Pierre Furter, Acta Africana, 1970, vol. IX, no 1, pp. 42-59

\&L'autogestion - aspiration historique de la classe ouvrière » par Mijalko Todorovic, Questions actuelles du socialisme, juil.-sept. 1970, no 99, pp. 3-31.

«Rôle des sciences sociales dans le développement $\gg$ Le mois à l'Unesco, juil.sept. 1970 , no 58 , pp. $28-30$.

«L'extension de l'homme par les systèmes homme-machine 》 par M.J. Farr, Revue de psychologie et des sciences de l'éducation, 1970 , vol. 5 , no 3 , pp. 286301 à pp. 302-308.

«The Anti-Industrial Revolution 》 by Ayn Rand, The Objectivist, Jan. 1971, vol. 10 , no 1 , pp. 1-8.

\section{Travail et main-d'oeuvre}

«Quelques considérations sur l'organisation du travail » par K.F.H. Murrell, Revue de psychologie et des sciences de l'éducation, 1970 , vol. 5 , no 3 , pp. 268-285 à pp. 286-301.

«La rentabilité de la formation professionnelle dans l'entreprise » par $\mathbf{R}$. Bonnell, Education permanente, juil.sept. 1970, no 7, pp. 19-37. 